The University of Maine

\title{
DigitalCommons@UMaine
}

Marine Sciences Faculty Scholarship

School of Marine Sciences

4-1-2007

\section{A Review of the Genus Iridogorgia (Octocorallia : Chrysogorgiidae) and Its Relatives, Chiefly from the North Atlantic Ocean}

Les Watling

University of Maine - Main, watling@maine.edu

Follow this and additional works at: https://digitalcommons.library.umaine.edu/sms_facpub

\section{Repository Citation}

Watling, Les, "A Review of the Genus Iridogorgia (Octocorallia : Chrysogorgiidae) and Its Relatives, Chiefly from the North Atlantic Ocean" (2007). Marine Sciences Faculty Scholarship. 9.

https://digitalcommons.library.umaine.edu/sms_facpub/9 


\title{
A review of the genus Iridogorgia (Octocorallia: Chrysogorgiidae) and its relatives, chiefly from the North Atlantic Ocean
}

\author{
Les Watling \\ Darling Marine Genter, University of Maine, Walpole, ME 04573, USA. Present address: Department of Zoology, University of \\ Hawaii at Manoa, Honolulu, HI 96822, USA. E-mail: Watling@hawaii.edu
}

\begin{abstract}
Exploration of the New England and Corner Rise Seamounts produced four new species of chrysogorgiid octocorals with the spiral iridogorgiid growth form. Three species are described as new in the genus Iridogorgia and one is described in the new genus Rhodaniridogorgia. Both genera have representatives in the Atlantic and Pacific Oceans. Iridogorgia magnispiralis sp. nov., is one of the largest octocorals encountered in the deep sea and seems to be widespread in the Atlantic.
\end{abstract}

\section{INTRODUGTION}

Verrill (1883) erected the genus Iridogorgia for a beautiful, spirally coiled, chrysogorgiid octocoral (I. pourtalesii) collected during the expeditions of the US Coast and Geodetic Steamer 'Blake' along the south-eastern US coast and into the West Indies. The original specimen, collected from off Dominica in $991 \mathrm{~m}$ (542 fms) of water, was approximately $20 \mathrm{~cm}$ high. This specimen was illustrated in volume 2 of the 'Blake' cruise narrative (Agassiz, 1888, p.145; see also Figure 1). Agassiz referred to it as 'a unique and striking species ... with its regular upright spiral main stem, and long, flexible, undivided branches, arranged in a single row nearly at right angles to the axis; forming a broad spiral like the skeleton of a spiral staircase' (op. cit., p. 144). Only a few branches remain from two specimens collected during the Blake expeditions. They are currently housed at both Harvard's Museum of Comparative Zoology (MCZ) and the Yale Peabody Museum of Natural History (YPM).

Nutting (1908) added the only other two additional species to this genus. Both specimens were collected in dredge hauls taken by the US Fish Commission Steamer 'Albatross' off the main Hawaiian Islands. One species, named by Nutting I. superba, was collected nearly entire, while the other, I. bella, was severely damaged and had only a few branches attached. The specimen of I. superba was described as being more than 5 feet $(\sim 1.5 \mathrm{~m})$ tall, but the piece of $I$. bella was only $9 \mathrm{~cm}$ high, although Nutting noted that the total length including the spiraling of the central axis was $32.5 \mathrm{~cm}$. Both specimens are in the collection of the Smithsonian Institution, although I. bella is represented by only a few branch pieces.

Recent exploration of the New England and Corner Rise Seamounts has produced four new species of 'iridogorgiids' from the North Atlantic Ocean. Three are typical members of the genus Iridogorgia while the other, along with Nutting's I. superba, is assigned to a new genus, Rhodaniridogorgia. As with I. pourtalesii and Nutting's Hawaiian species, all are from deep, cold water. These specimens were found and collected through the use of modern submersibles and remotely operated vehicles (ROVs). As more areas of the deep sea are explored with these devices, many more specimens of deep, cold water dwelling corals will be found.

\section{MATERIALS AND METHODS}

All new species described here were collected as part of three expeditions to the New England and Corner Rise Seamounts. The first two expeditions, conducted in 2003 and 2004, were named Mountains-in-the-Sea I and II, respectively, and the 2005 expedition was named Deep Atlantic Stepping Stones. L. Watling was Chief Scientist on all three expeditions and can be contacted for details. Summaries of all expeditions can be found on the web site of NOAA's Ocean Exploration Program (currently www. oceanexplorer.noaa.gov).

Specimens were obtained by use of the deep submergence vehicle (DSV) 'Alvin', in 2003 and the remotely operated vehicle (ROV) 'Hercules', in 2004 and 2005. In all cases, specimens were collected by use of a manipulator equipped with a claw that could break (in the case of 'Alvin') or cut (in the case of 'Hercules') off pieces of large colonies, or remove entire small colonies from the substrate. All collected colonies or pieces of colonies were put in an insulated collection box on the vehicle for return to the research vessel. On board, the specimens were kept in cold seawater until they could be fixed and preserved. After removal of colony pieces for genetic and reproductive studies, all specimens were fixed in a dilute formalin solution (4\%) for 12 hours and then rinsed and stored in $70 \%$ ethanol.

Sclerites were dissolved from the surrounding polyp and branch tissue using household bleach. Following several washings in deionized water, individual sclerites were mounted on standard scanning electron microscope (SEM) stubs with blackened double-sided tape. Individual polyps to be examined with SEM were removed from a branch, dehydrated to $100 \%$ ethanol, and dried using a Samdri Critical Point Dryer. Digital images of sclerites and polyps were obtained using a Hitachi S-800 SEM fitted with a 


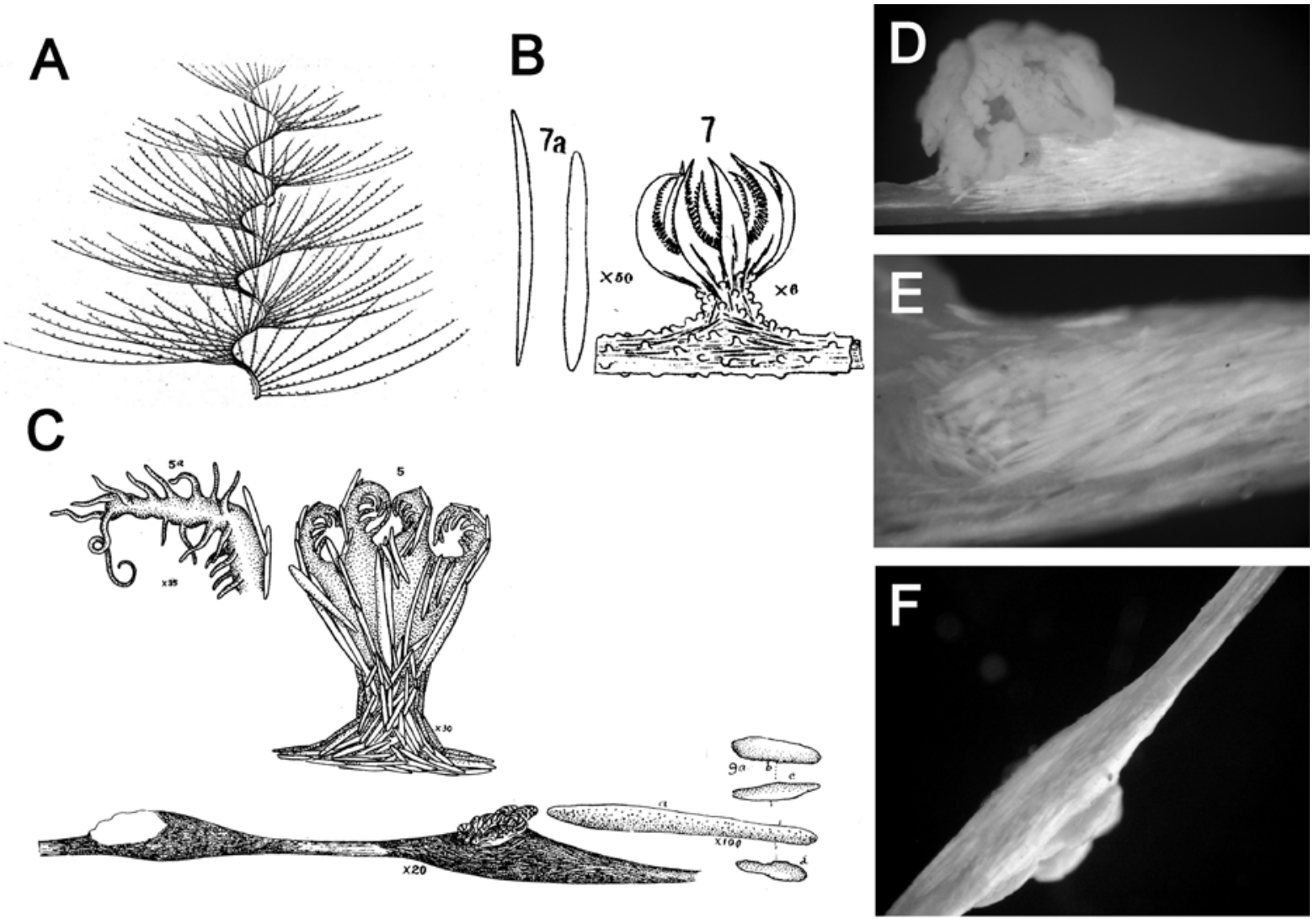

Figure 1. Iridogorgia pourtalesii Verrill, 1883. (A) Drawing of the first specimen taken by the Steamer 'Blake' (from Agassiz, 1888); (B) drawings of the sclerites and polyp (from Verrill, 1883); (C) further drawings of the species from Verrill's recently discovered unpublished plates; D-F, photographs of the holotype, MCZ no. 4863.

digital capture board. All sclerite and polyp images used in this paper were isolated from the original image background using Adobe Photoshop, but the images are otherwise unaltered in accordance with current scientific image processing guidelines.

\section{SYSTEMATICS \\ Subclass OCTOCORALLIA \\ Order ALCYONAGEA \\ Family CHRYSOGORGIIDAE Verrill, 1883 \\ Genus Iridogorgia Verrill, 1883}

Iridogorgia: Versluys, 1902: 91; Nutting, 1908: 594; Kukenthal, 1919: 538, 1924: 408; Deichmann, 1936: 234.

\section{Type species}

Iridogorgia pourtalesii Verrill, 1883, by monotypy.

\section{Diagnosis}

Main axis monopodial, spiraling upward, with undivided branches emanating from one side of axis. Polyps short, when sexually mature with base expanded along upper side of branch. Sclerites rods, spindles, or scales, arranged vertically, extending in tracts onto tentacles. Branch coenenchyme with sclerites oriented along branch or without sclerites between polyps.

\section{Additional species}

Iridogorgia bella Nutting 1908, I. fontinalis sp. nov., I. magnispiralis sp. nov., I. splendens sp. nov.

\section{Iridogorgia pourtalesii Verrill, 1883}

(Figure 1)

Iridogorgia pourtalesii: Verrill, 1883: 26; Agassiz, 1888: 144; Versluys, 1902: 92; Kükenthal, 1919: 539; Kükenthal, 1924: 409; Deichmann, 1936: 235; Bayer, 1956: F216.

\section{Type material}

Holotype: Blake Station 190, off Dominica, $15.303^{\circ} \mathrm{N}$ $61.442^{\circ} \mathrm{W}$, depth $542 \mathrm{fms}$ (975 m), MCZ no. 4863, branches only; YPM no. 2395.

\section{Other material examined (non type)}

Blake Station 259, off Grenada, 159 fms (286 m), MCZ no. 4865. Note: Deichmann (1936: 236) concluded, and I agree that the depth for Station 259 must be in error as too shallow.

\section{Diagnosis}

Polyps low along the branches, spaced approximately every 5-6 $\mathrm{mm}$; polyp sclerites longitudinally arranged to base of tentacles; polyp and branches with low verrucae; inter-polyp coenenchyme without sclerites. 

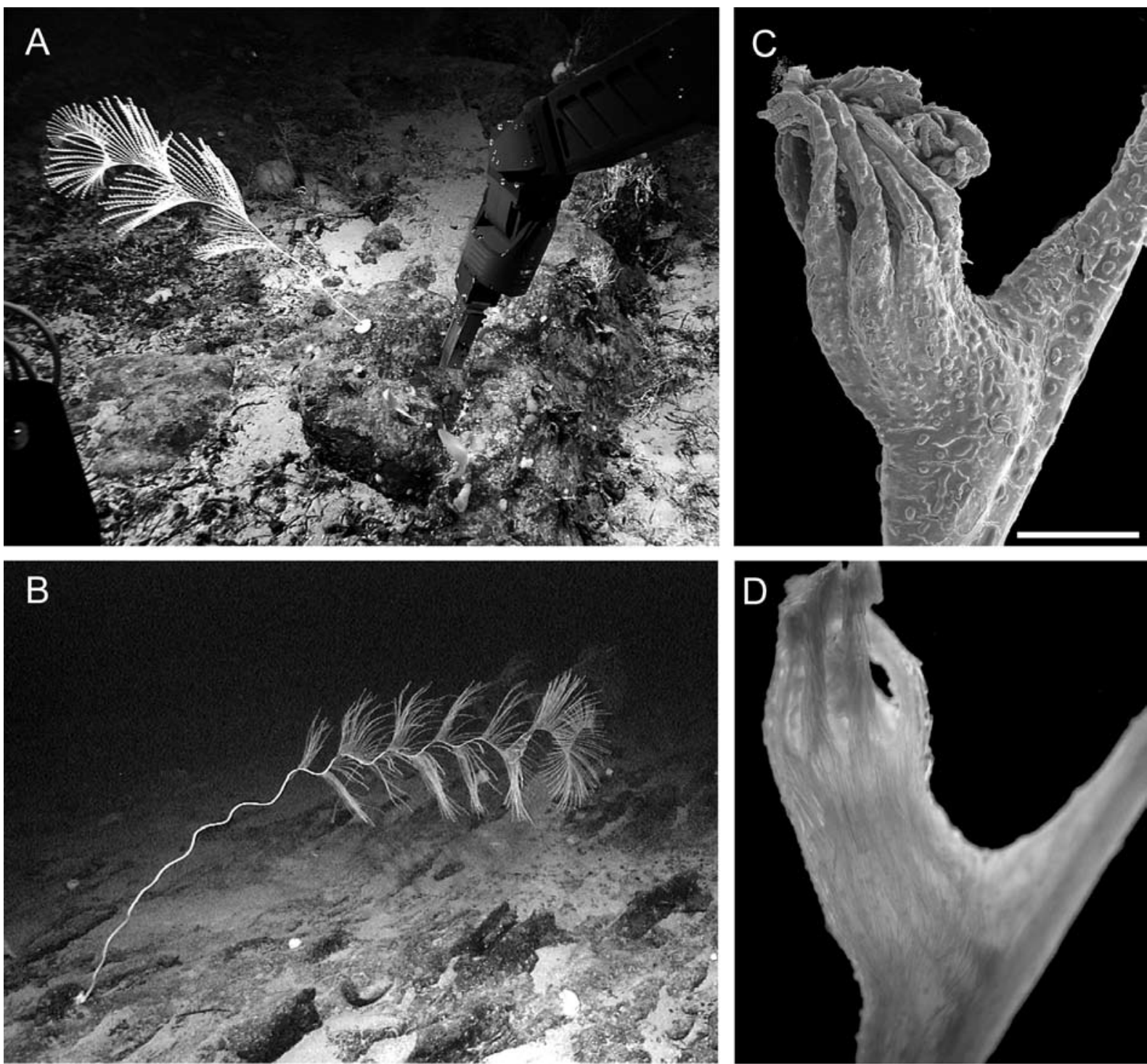

Figure 2. Iridogorgia magnispiralis sp. nov. (A) Holotype specimen in situ before being collected; (B) a large specimen at $2200 \mathrm{~m}$ on Nashville Seamount; (C) SEM of critical-point dried polyp from holotype; (D) light microscope photo of holotype polyp; note arrangement of sclerites vertically along polyp body wall. Scale bar: $1 \mathrm{~mm}$.

\section{Description}

Modified from Verrill (1883) and Deichmann (1936). The main stem is strong, somewhat rigid, growing in a remarkably regular, open, upright spiral or helix. The base was not collected. The type measured about $20 \mathrm{~cm}$ in height, including about five helical revolutions. The central axis was $2 \mathrm{~mm}$ thick at the lower part, tapering to a slender and acute apex. Branches were numerous, undivided, and arose regularly at right angles, approximately $3-6 \mathrm{~mm}$ apart, along one side of the central axis. The branches are about 1 $\mathrm{mm}$ wide at base, tapering delicately to the tip.

The polyps, with rare exceptions, are present only on the branches, spaced approximately $5 \mathrm{~mm}$ apart. The polyps are usually broader than the branch on which they sit, their swollen basal part extending along the branch. The tentacles, with their elongated pinnulae, are incapable of complete retraction.

The tissue is thin along the branches, often with numerous small protuberances, or verrucae, (termed nematozooids by Deichmann), but with few or no small sclerites.
The sclerites in the polyps are nearly smooth spindles, and average about $400 \mu \mathrm{m}$ in length. The polyp sclerites are arranged slightly obliquely at the base, becoming longitudinal below the base of the tentacles. Tentacle sclerites are longitudinally arranged, sparse, and from 200 to $900 \mu \mathrm{m}$ in length. Pinnulae are without sclerites.

\section{Distribution}

This species is known so far from two specimens collected by the 'Blake' in the West Indies and a specimen collected by the US Coast Survey Steamer 'Bibb' from the Florida Straits at $310 \mathrm{fms}(558 \mathrm{~m})$.

\section{Remarks}

Deichmann (1936) apparently was the last person to see the complete piece of this species, although she noted it was 'fragmentary'. All that remains in the collections of both Harvard's Museum of Comparative Zoology and the Yale Peabody Museum are branch pieces approximately 5-10 $\mathrm{cm}$ in length. Iridogorgia pourtalesii can be distinguished from 


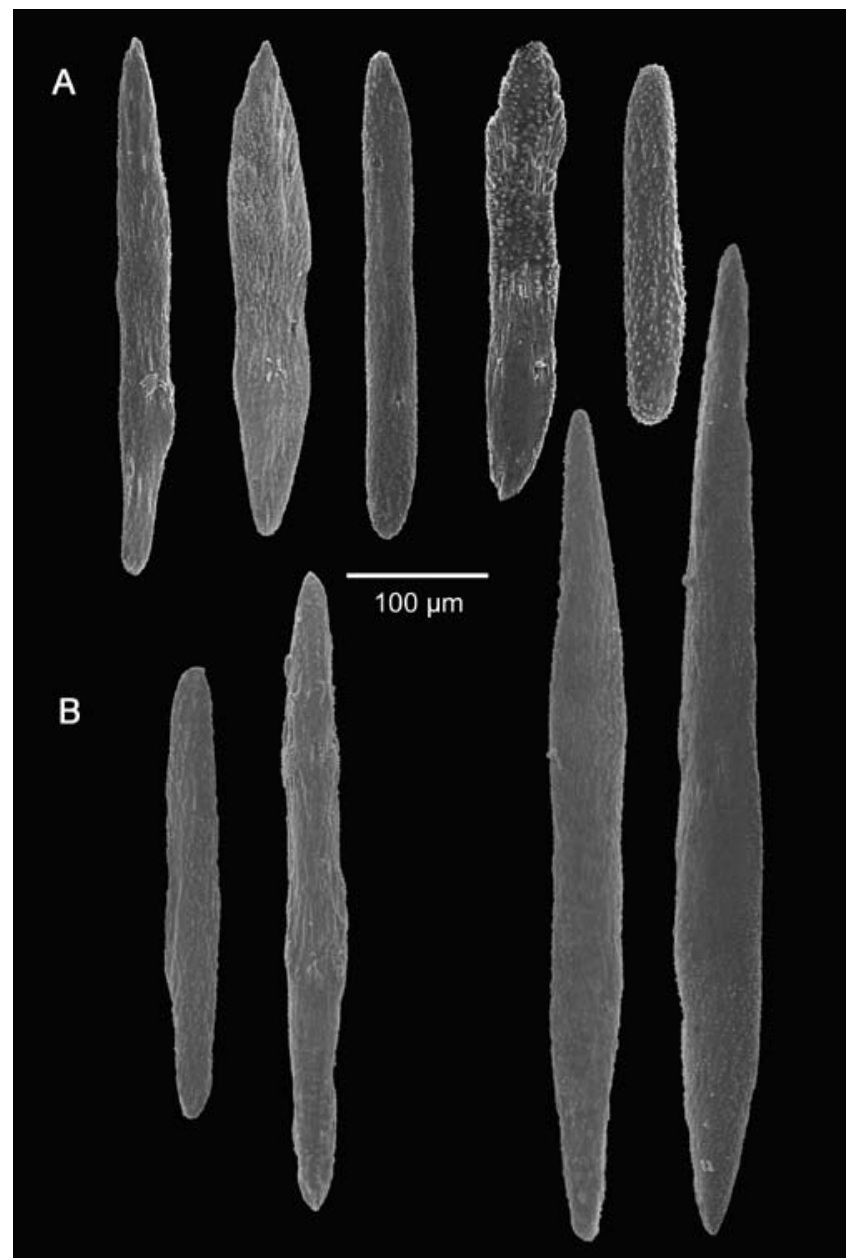

Figure 3. Iridogorgia magnispiralis sp. nov. (A) Sclerites from polyp; (B) sclerites from branch coenenchyme.

all other species in the genus by the lack of sclerites along the branches between the polyps, and the relatively long sclerites in the polyp body wall. This species will need to be re-collected, however, so that a complete redescription can be made.

\section{Iridogorgia magnispiralis sp. nov.}

(Figures $2 \& 3$ )

\section{Type material}

Holotype: Kelvin Seamount, Station 403-2, 3846.746'N $63^{\circ} 57.770$ 'W, $2311 \mathrm{~m}, 19$ May 2004, top $65 \mathrm{~cm}$ of large colony collected (measured along axis, about 1.5 helical turns), YPM 38580, GenBank IDs DQ860108 and DQ860111.

Paratypes: Nashville Seamount, Station NAS 205-2, $34^{\circ} 28.64^{\prime} \mathrm{N} 56^{\circ} 44.02^{\prime} \mathrm{W}, 2143 \mathrm{~m}, 26$ August 2005, top 25 $\mathrm{cm}$ (almost one full helical turn) of colony collected, YPM 38583; Manning Seamount, Station MAN 102-1,38¹5.80'N $60^{\circ} 32.975^{\prime} \mathrm{W}, 1718 \mathrm{~m}, 13$ July 2003, upper $30 \mathrm{~cm}$ collected (measured along axis, not quite one full helical turn) YPM 38581; Kelvin Seamount, Station KEL 203-5, 38 ${ }^{\circ} 51.506^{\prime} \mathrm{N}$ $63^{\circ} 54.846^{\prime} \mathrm{W}, 2047 \mathrm{~m}, 16$ July 2003, juvenile $25 \mathrm{~cm}$, axis only slightly coiled, YPM 38582; Nashville Seamount, Station NAS 102-2, $34^{\circ} 34.977^{\prime} N$ 56 50.60'W, 2248 m, 25 August 2005, top $38 \mathrm{~cm}$ of colony collected (measurement is of two helical turns, about $19 \mathrm{~cm}$ each, helix diameter about
7-9 cm), USNM 1092265; Nashville Seamount, Station NAS 205-1, 34 $28.64^{\prime} \mathrm{N} 56^{\circ} 44.02^{\prime} \mathrm{W}, 2143$ m, 26 August 2005, juvenile $35 \mathrm{~cm}$ (measured as total height, about 1.5 helical turns) USNM 1092266.

\section{Diagnosis}

Polyps erect along the branches, spaced approximately every 6-7 $\mathrm{mm}$; polyp sclerites longitudinally arranged to base of tentacles; coenenchyme with few low verrucae; interpolyp coenenchyme with numerous sclerites.

\section{Description}

An adult colony may be very large, up to $2.5 \mathrm{~m}$ in overall height (as measured in photographs), with a very large and spacious helical structure which spirals clockwise upward. The largest colonies imaged have 12-13 helical turns in the central axis, with each complete turn about $15-20 \mathrm{~cm}$ in height and 7-9 $\mathrm{cm}$ in diameter in the upper part of the colony. Colonies are attached to the substrate by a roughly circular, flattened (not rhizoidal) holdfast, 2-4 cm in diameter. The central axis at the base may be $1-2 \mathrm{~cm}$ in diameter. Branches are arranged along one side of the central axis, originating every $4-5 \mathrm{~mm}$. Branches are approximately 150 to $250 \mathrm{~mm}$ in length. Polyps are arranged along the upper (down-current) side of the branch, approximately 6-7 mm apart, and are tilted toward the distal tip of the branch. Polyps and branches have evenly-spaced verrucae which house approximately 50-100 cnidae each. Cnidae do not seem to be present outside the verrucae and are not visible (perhaps not present?) in the tentacle pinnules.

Polyps are elongate, about $1-1.5 \mathrm{~mm}$ diameter and 1 $\mathrm{mm}$ from the branch to the tentacle bases. Tentacles are 2-3 $\mathrm{mm}$ in length in preserved material. Photographs taken in situ show the tentacles to be about two times the length of an expanded polyp. Polyp sclerites are angled at the base where the polyp is attached to the branch, then are arranged vertically from the base to, and along, the outer surface of the tentacles. Sclerites at the base and along the wall of the polyp are flattened to slightly rounded spindles averaging 307×45 $\mu \mathrm{m}$ (range: $224-383 \times 23-57 \mu \mathrm{m}$ ); those in the tentacles are bluntly rounded rods about $296 \times 36 \mu \mathrm{m}$ (range: $254-347 \times 30-42 \mu \mathrm{m}$ ).

The calcified branch axis is approximately $45-47 \mu \mathrm{m}$ in diameter. Sclerites from along the branch are long spindles averaging $552 \times 50 \mu \mathrm{m}$ (range: $322-734 \times 37-64 \mu \mathrm{m})$. Sclerites are present along the entire length of the branch.

\section{Etymology}

From L., magni $=$ large and spiralis $=$ spiral, indicative of the very large size of the helical spiral in this species.

\section{Distribution}

This species has been either collected or observed in video sequences from the western Corner Rise Seamounts through the New England Seamounts as far west as Kelvin Seamount. There are also images taken at the Lost City site on the Mid-Atlantic Ridge that seem to be of this species. No specimens were collected, however, at the latter site. The depth range for all observations is from about $1650 \mathrm{~m}$ to $2400 \mathrm{~m}$. 



Figure 4. Iridogorgia splendens sp. nov. holotype. (A) Colony in situ; (B) light microscope photograph of polyp; (C) same, with polyp opened to show presence of eggs under the swelling that develops at the polyp base when the colony becomes reproductive; (D) SEM image of critical-point dried polyp. Scale bar: $1 \mathrm{~mm}$.

\section{Remarks}

This species is distinctive in its overall size, reaching $2 \mathrm{~m}$ or so in height, but also in the large size of individual helices in the spiral. This latter feature allows one to identify juveniles as small as $25 \mathrm{~cm}$ or so in height in video or still images.

\section{Iridogorgia splendens sp. nov.}

(Figures 4 \& 5)

\section{Type material}

Holotype: Rehoboth Seamount, Station REH 104-2, $37^{\circ} 27.64^{\prime} \mathrm{N} 59^{\circ} 57.09^{\prime} \mathrm{W}, 1911 \mathrm{~m}, 28$ August 2005, entire colony collected in two parts $61 \mathrm{~cm}$ in total length, YPM 38585.

Paratypes: Kelvin Seamount, Station KEL 105-1, $38^{\circ} 47.33^{\prime} \mathrm{N} 64^{\circ} 07.86^{\prime} \mathrm{W}, 1986 \mathrm{~m}, 15$ July 2003, most of colony collected, $49 \mathrm{~cm}$ total length, USNM 1092267; Kelvin Seamount, Station KEL 502-1, 38 ${ }^{\circ} 51.22^{\prime} \mathrm{N} 63^{\circ} 45.81^{\prime} \mathrm{W}$, $2054 \mathrm{~m}, 20$ May 2004, juvenile, $30 \mathrm{~cm}$ near total length, YPM 38586, GenBank IDs DQ860109 and DQ860112; Kelvin Seamount, Station 618-2, 38 ${ }^{\circ} 46.39^{\prime} \mathrm{N} 64^{\circ} 05.29^{\prime} \mathrm{W}$, $1844 \mathrm{~m}, 01$ September 2005, juvenile, $19 \mathrm{~cm}$ near total length, YPM 38587.

\section{Diagnosis}

Colony short, up to about $65 \mathrm{~cm}$ in height, central axis with as many as 13 helical turns, each about $5 \mathrm{~cm}$ in height and 1-2 cm diameter. Sclerites abundant in lower part of polyps only, coenenchyme devoid of sclerites along branches. Some polyp and branch sclerites with mid-length constriction. 


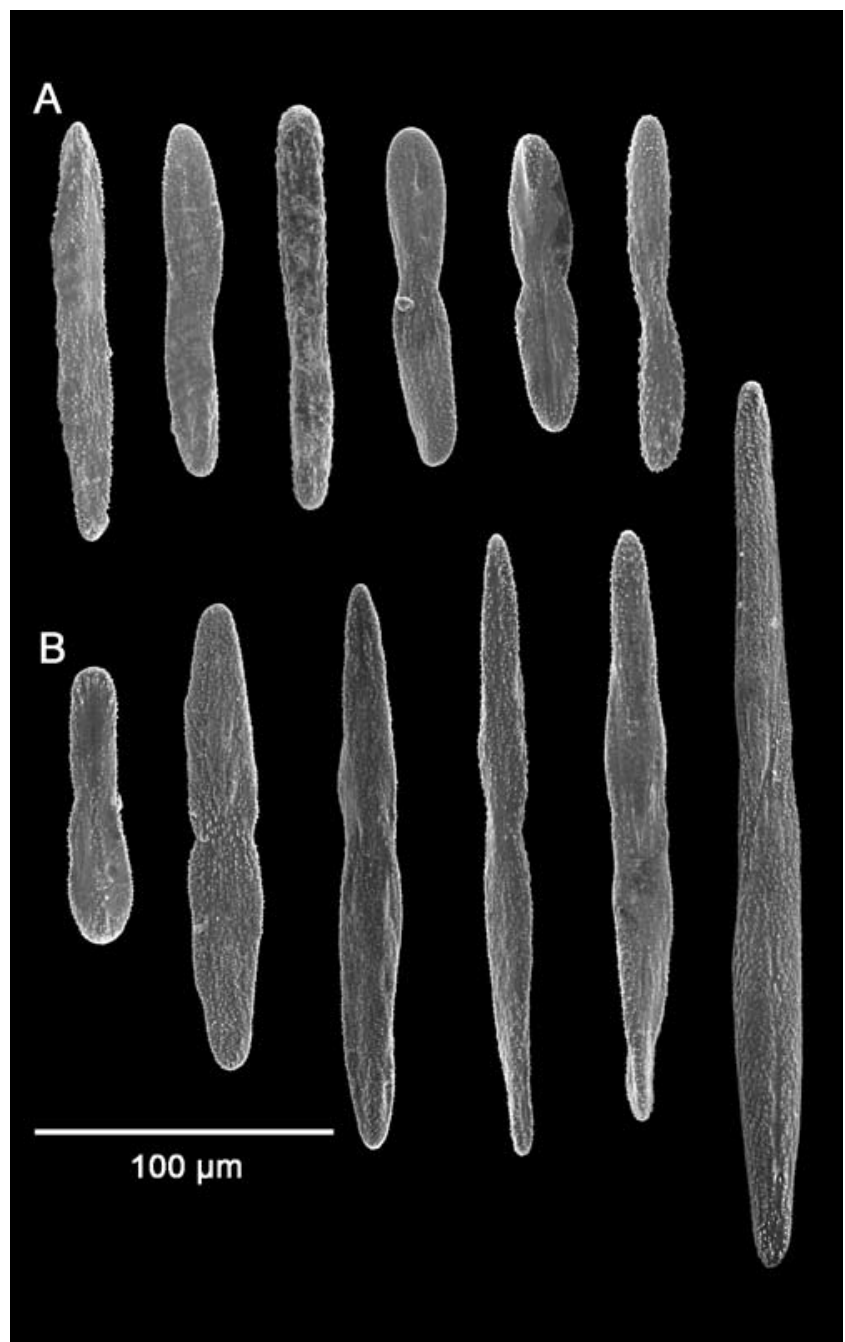

Figure 5. Iridogorgia splendens sp. nov. holotype. (A) Sclerites from polyp; (B) sclerites from along branch.

\section{Description}

The largest adult colony collected is about $61 \mathrm{~cm}$ in height, its central axis encompassed 13 helical turns, spiralling clockwise upward, reaching a helix diameter of about $2 \mathrm{~cm}$ and height of $5 \mathrm{~cm}$. The central axis at the base has a diameter of $3.5 \mathrm{~mm}$. In younger colonies the central axis varies from 1.5 to $2.6 \mathrm{~mm}$ in diameter, the number of helical turns from 5 to 10 , and the helix diameter from $1-1.5 \mathrm{~cm}$. Colonies are attached to the substrate by a small circular, flattened (non-rhizoidal) holdfast, about $1 \mathrm{~cm}$ in diameter. Branches are arranged along one side of the central axis, originating every 3-4 mm. Branches in the central part of the colony range in length from 140 to $155 \mathrm{~mm}$. Polyps are arranged along the upper side of the branches from 6 to $8.5 \mathrm{~mm}$ apart. Polyps and branches have numerous verrucae housing large numbers of cnidae under a thick layer of tissue.

Polyps are short, extending less than $1 \mathrm{~mm}$ from the branch to the tentacle base. When containing eggs, the base of the polyp is swollen and expanded along the branch for $1-2 \mathrm{~mm}$ in each direction. The tentacles are delicate, with few rod-like sclerites (mean size: $229 \times 33 \mu \mathrm{m}$; range $169-274 \times 27-39 \mu \mathrm{m})$ only at the base. The lower portion of the polyp, especially when swollen, has abundant scaleshaped sclerites, most with a constriction midway along their length. The short scales average $185 \times 35 \mu \mathrm{m}$ (range: 143-228×30-43 $\mu \mathrm{m})$, and the elongated scales $249 \times 39 \mu \mathrm{m}$ (range: 216-268×29-45 $\mu \mathrm{m}$ ).

The calcified branch axis measures 136 to $151 \mu \mathrm{m}$ with the tissue removed. Sclerites along the branch under the polyp range from constricted scales as seen in the polyp, gradually becoming more elongate to spindles with a slight constriction, to very long spindles. The elongated scales average $341 \times 41 \mu \mathrm{m}$ (range: $274-493 \times 31-51 \mu \mathrm{m})$ and the spindles $427 \times 38 \mu \mathrm{m}$ (range: $291-592 \times 24-46 \mu \mathrm{m})$. Sclerites are absent to rare in the coenenchyme between polyps.

\section{Etymology}

From L., splendor = brilliance, splendid, resplendent, all terms that readily come to mind when this species is observed in situ.

\section{Distribution}

Known only from the New England seamounts Balanus, Kelvin, Rehoboth, and Nashville, 1700-2200 m.

\section{Remarks}

This species can be distinguished in situ by the relatively tightly coiled central axis which extends for several turns, even in young specimens. In the smallest juveniles the branches extend laterally only for $10 \mathrm{~cm}$ or so on each side, increasing in length with age. The branch axis in this species is much thicker than in the I. magnispiralis, even though the latter overall grows to be a much larger colony. The larger branch axis may be a response to the loss of sclerites from the branch coenenchyme. Iridogorgia splendens usually occurs in areas where the deep currents are not strong, allowing its branches to extend outward in graceful arcs, making it one of the most beautiful of the deep-dwelling octocorals.

\section{Iridogorgia fontinalis sp. nov.}

(Figures 6 \& 7)

\section{Type material}

Holotype: Corner Rise Seamounts, Station MIL 111-1, $34^{\circ} 48.76^{\prime} \mathrm{N} 50^{\circ} 30.23^{\prime} \mathrm{W}, 1325 \mathrm{~m}, 17$ August 2005, $19 \mathrm{~cm}$ (nearly all) of colony collected, YPM 38584, GenBank ID DQ860110.

\section{Diagnosis}

Colony short and compact, helix diameter $2.5 \mathrm{~cm}$, upper five helices with branches. Branches moderately long (140-150 mm) closely spaced (1-2 mm) along central axis, and angled upward. Polyp sclerites all rod-shaped, scales absent.

\section{Description}

Only one colony has been collected. The central axis forms several helices about $2.5 \mathrm{~cm}$ in diameter and $4 \mathrm{~cm}$ in height. Only the upper five helices bear branches, and these are set about 1-2 $\mathrm{mm}$ apart, are 140-150 mm long, and are directed upward at about a 30 degree angle from the outer side of the central axis. Polyps are arranged at intervals of 5-9 $\mathrm{mm}$ along the upper sides of the branches. The base of the colony could not be imaged during the collection process as it seemed to be anchored within the substrate. 

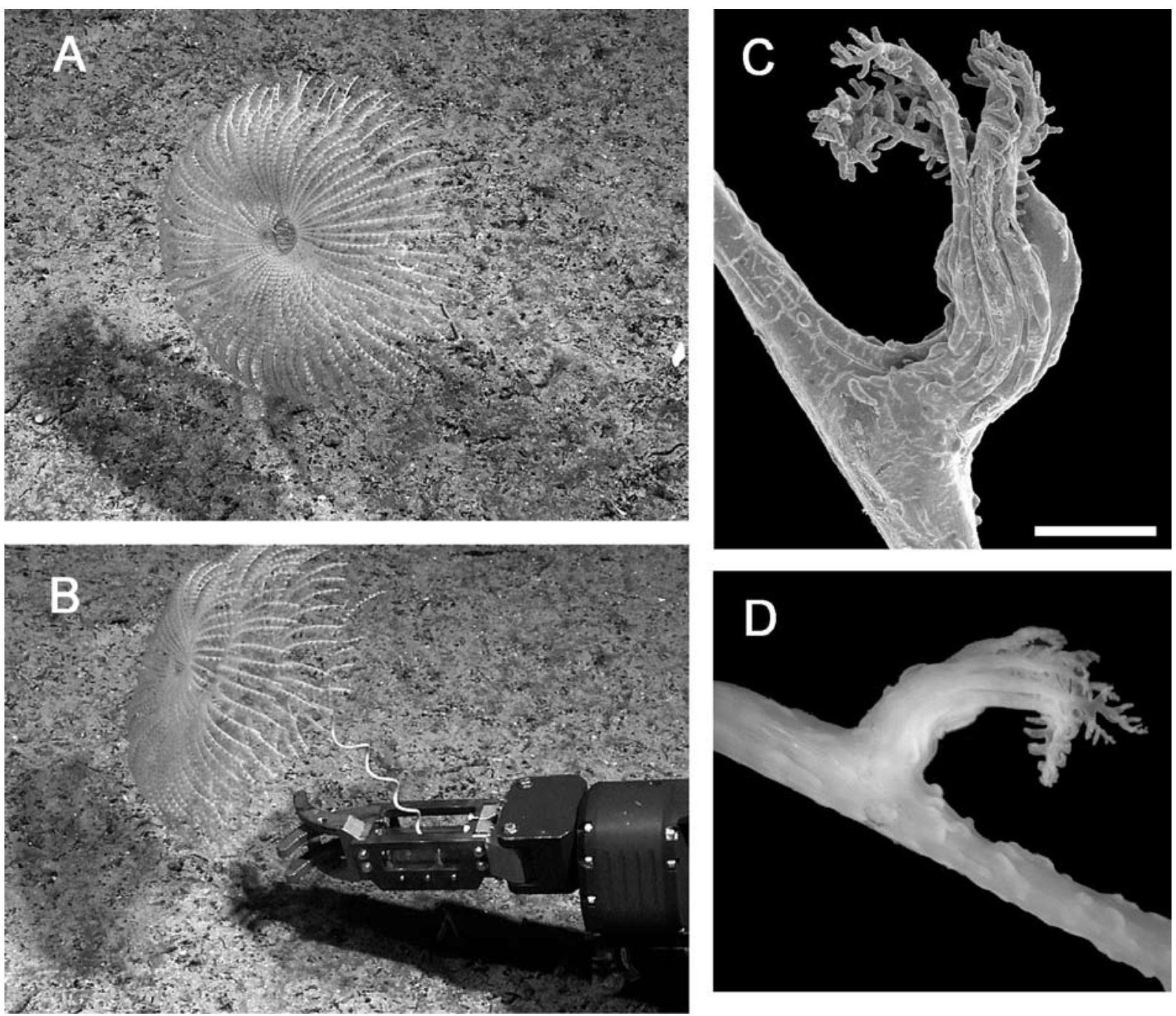

Figure 6. Iridogorgia fontinalis sp. nov. holotype. (A) Colony viewed from above; (B) colony seen from the side during collection; (C) SEM image of critical-point dried polyp; (D) light microscope image of polyp and branch; note elongate shape of verrucae. Scale bar: $1 \mathrm{~mm}$.

Polyps and branches are covered with large and irregularly spaced verrucae bearing large numbers of cnidae.

Polyps are about $1 \mathrm{~mm}$ in height from the branch to the base of the tentacles. In this specimen the polyp base is not swollen, perhaps because the colony is not reproductively mature. Sclerites are arranged along the length of the branch, becoming less numerous between the polyps, and gradually turn to be oriented vertically in the polyp and along the outer surface of the tentacles. The polyp and tentacle sclerites are all rods of various kinds (average size $347 \times 38 \mu \mathrm{m}$; range: $175-482 \times 27-50 \mu \mathrm{m}$ ), the shorter rods being found in the tentacles. The branch sclerites are mostly spindles with a few flattened and elongated scales. The spindles average $694 \times 51 \mu \mathrm{m}$ (range $397-1024 \times 25-74 \mu \mathrm{m})$ in size.

\section{Etymology}

From L., fontinalis = of a spring, fountain, because of the upwardly-directed branches which evoke the shape of the water spray from a circular fountain.

\section{Distribution}

Known only from the type locality.

\section{Remarks}

The overall shape of the colony is distinctive within the genus as is the very close spacing of the branches emanating from the coiled central axis. This species is somewhat unusual in not having scale-like sclerites in the polyp.

\section{Rhodaniridogorgia gen. nov.}

\section{Type species}

Rhodaniridogorgia fragilis sp. nov., here designated.

\section{Diagnosis}

Central axis wavy, not coiled; branches emanate in a spiral around central axis. Sclerites a broad mix of shapes from scales to spindles, including some superficially similar to the 'styles' of sponges, and others with side protrusions or flattened crosses.

\section{Etymology}

From Gr., rhodanos = wavy, waving, + iridogorgia .

\section{Other species}

Rhodaniridogorgia superba (Nutting, 1908). 


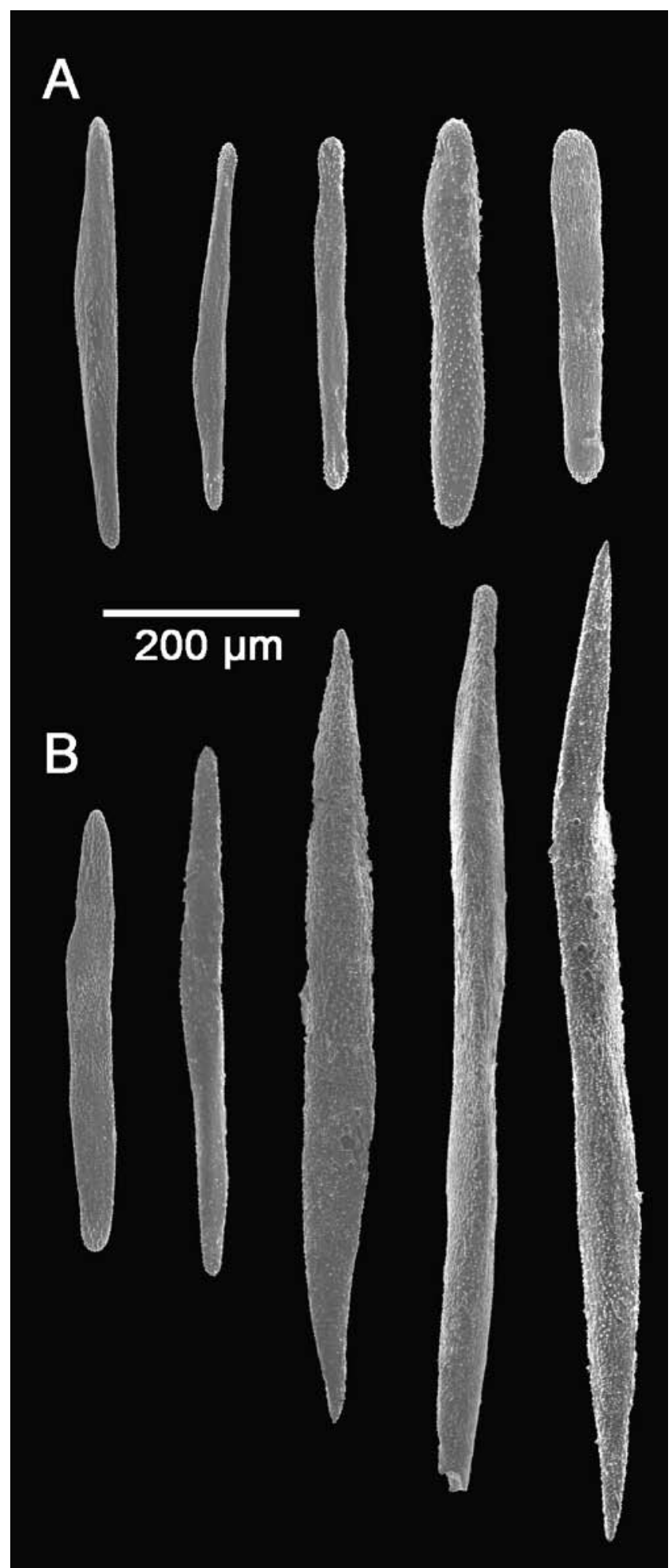

Figure 7. Iridogorgia fontinalis sp. nov. holotype. (A) Sclerites from polyp; (B) sclerites from along branch.

\section{Remarks}

While clearly closely related to the genus Iridogorgia, species in this new genus do not have a spirally coiled central axis. That feature, coupled with the very different array of sclerites in both the polyp and branch coenenchyme distinguish both Rhodaniridogorgia species from all species of Iridogorgia. Nutting (1908), curiously, noted the wavy appearance of the central axis and the helical arrangement of the branches around the central axis, but did not otherwise comment on how that differed from the arrangement seen in other species of Iridogorgia where the central axis is twisted into a spiral with the branches emanating from one side.

Rhodaniridogorgia fragilis sp. nov.

(Figures 8 \& 9)

\section{Type material}

Holotype: Nashville Seamount, Station NAS 208-1, $34^{\circ} 28.56^{\prime} \mathrm{N} 56^{\circ} 43.98^{\prime} \mathrm{W}, 2229 \mathrm{~m}, 26$ August 2005, top 46 $\mathrm{cm}$ (approximately half) of colony collected, YPM 38588, GenBank ID DQ860107.

\section{Diagnosis}

Branches long (220-300 mm), set somewhat widely apart (3.6-6.0 mm) along the wavy central axis. Sclerites a wide range of shapes from rods to scales and spindles, present throughout the branches and polyps.

\section{Description}

Only one colony was seen and the top section collected. The central axis was nearly straight at the base, becoming wavy and slightly twisted upwards. The holdfast of the colony is not clear in the video image but appears to be an irregular flattened disc about $5 \mathrm{~cm}$ or so across. Branches originate from 3.5 to $6 \mathrm{~mm}$ apart in a spiral arrangement around the central axis, forming whorls of 15 to 19 branches over a distance up the central axis of 60 to $80 \mathrm{~mm}$. Branches measure from 220 to $280 \mathrm{~mm}$ in length and bear polyps every $6-7 \mathrm{~mm}$. Verrucae are not present on either the polyp body wall or along the branch. Very small cnidae $(\sim 10 \mu \mathrm{m}$ in length) were observed (using SEM) in the tentacle pinnules but not elsewhere on the polyp.

Polyps are $1-1.5 \mathrm{~mm}$ in diameter and extend $1-2 \mathrm{~mm}$ from the branch to the base of the tentacles. The tentacles are about $2 \mathrm{~mm}$ in length and $0.5 \mathrm{~mm}$ in diameter. The polyp is very heavily armoured with sclerites, there being no part of the polyp body wall or outer side of the tentacles without sclerites. The polyp sclerites show a wide range of shapes, including elongate flattened spindles (177-418 $\mu \mathrm{m}$ length), rods (357-455 $\mu \mathrm{m}$ length), scales with constrictions or protuberances and short scales $(177-330 \times 35-78 \mu \mathrm{m})$, and crosses (each axis 100-139 $\mu \mathrm{m}$ in length). From the polyp body to the branch there is a transition of sclerite shapes from short scales at the base of the polyp to elongate spindles and thickened 'styles' (in the sense of the spicule commonly seen in sponges) in the branch. At the base of the polyp body there is a very high incidence of sclerites with large rounded protuberances or taking the shape of a skewed cross. Along the underside of the branch the sclerites are predominantly large spindles. Branch scales range in size from 109-378×25$98 \mu \mathrm{m}$, and the spindles $380-574 \times 37-54 \mu \mathrm{m}$.

\section{Etymology}

From L., fragilis = easily broken, fragile, recognizing the frustration in handling this specimen whose branches readily break away from the central axis.

\section{Distribution}

Known only from the type locality. 

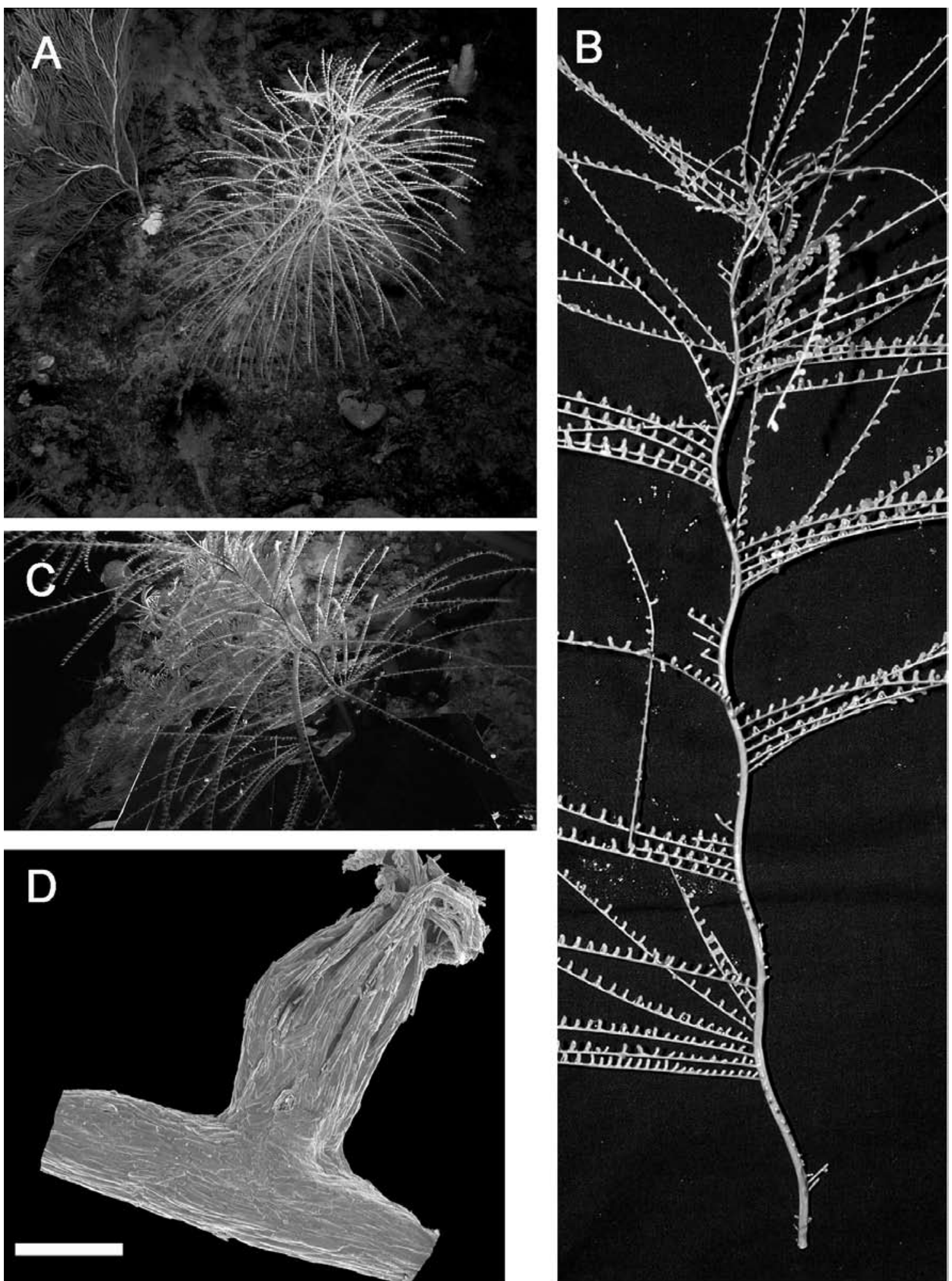

Figure 8. Rhodaniridogorgia fragilis sp. nov. holotype. (A \& C) In situ images of holotype specimen before and during collection; (B) holotype photographed in the laboratory aboard ship; (D) SEM image of critical- point dried polyp. Scale bar: $1 \mathrm{~mm}$.

\section{Remarks}

This species differs from the only other species in the genus, R. superba (taken from about 600-900 $\mathrm{m}$ off the Hawaiian Islands), by its longer branches, greater helix height of the spiraling branches, and more varied sclerite morphologies. While Nutting (1908) did not illustrate the whole colony of $R$. superba, the specimen, measuring about $1.5 \mathrm{~m}$ overall, can be found in the collection of the Smithsonian's National Museum of Natural History. Nutting noted 'this was the handsomest alcyonarian that the writer has ever seen as it came up in the trawl' (1908: 596). One can make a similar statement about all of the iridogorgiids, which routinely draw comments on their beauty from onlookers as the ROV collection boxes are emptied on board the ship. 


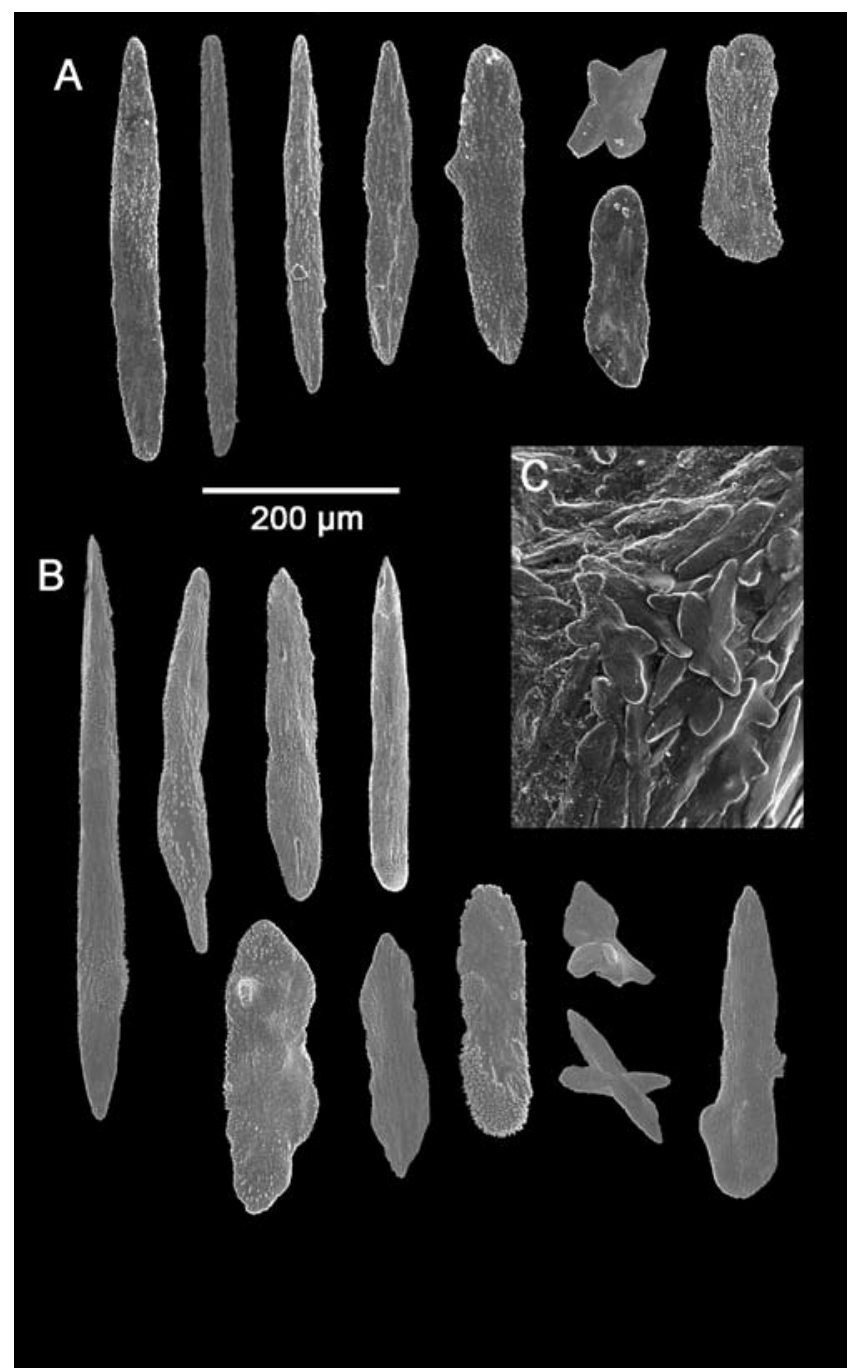

Figure 9. Rhodaniridogorgia fragilis sp. nov. holotype. (A) Sclerites from polyp; (B) sclerites from branch and polyp base; (C) SEM image of area at polyp base where the transition to the branch sclerites occurs.

\section{DISCUSSION}

Iridogorgiids appear to be common inhabitants of seamounts, island ridges, and rocky continental slopes in both the Atlantic and Pacific Oceans. Most likely they will be found throughout the world's oceans as more 'inaccessible' areas are explored with submersibles and ROVs. There are at least two remaining undescribed species with the general growth form of Iridogorgia magnispiralis known from the North Pacific, and others have been seen in photographs from the south-western Pacific. At present, iridogorgiids in the Atlantic are restricted to deeper waters with temperatures around $4{ }^{\circ} \mathrm{C}$, but they may be found slightly shallower in the Pacific where temperatures are as high as $8^{\circ} \mathrm{C}$.

The iridogorgiid growth form, with its spiral axis, is quite unusual, although not unique, among the octocorals (Bayer, 1973). Other spiral forms, however, are not branched. Hints of a spiral arrangement of the central axis can be seen in other members of the Chrysogorgiidae. For example, in the genera Radicipes and Simpsonella, the central axis is often coiled but the colony is unbranched (Kükenthal, 1919; Williams, 1992). One group of the widespread and diverse genus, Chrysogorgia, possesses a relatively slender zig-zag central axis where each branch emanates at a fixed angle to the one below, producing a spiral effect. In Rhodaniridogorgia, the central axis is wavy (?a thickened zig-zag) and the branches, compared to species of Chrysogorgia, are more numerous and truly spirally arranged. Finally, in Iridogorgia, the central axis itself is a true spiral with branches produced from along one side. Future studies will examine the phylogenetic relationships among all these genera, utilizing molecular data currently being processed from these specimens.

This study was made possible by generous funding from NOAA's Ocean Exploration programme. I would like to thank my coprincipal investigators, P. Auster, S. France, I. Babb, L. Mullineaux, J. Moore, for their help in securing the funding and, along with $\mathrm{T}$. Shank and his crew, for their vigilance during long ROV dives in spotting iridogorgiids. The careful imaging and collection of these beautiful specimens was facilitated through the expertise of the captain and crew of the RV 'Atlantis' and NOAA ship 'Ronald H. Brown', the pilots of the DSV 'Alvin' and the pilots, navigators, camera operators, and technicians responsible for the ROV 'Hercules'. A number of students, including my graduate students A. Simpson and C. Mosher, helped with the fixation and handling of the specimens. All SEM work was conducted under the friendly and able guidance of T. Carvalho at the University of Hawaii PBRC Electron Microscope Facility. Scott France provided the GenBank sequences. The holotype specimen of Iridogorgia pourtalesii was graciously loaned by A. Johnson.

\section{REFERENGES}

Agassiz, A., 1888. Three cruises of the United States Coast and Geodetic Steamer 'Blake' in the Gulf of Mexico, in the Caribbean Sea, and along the Atlantic coast of the United States, from 1877 to 1880. 2 vols. Boston: Houghton, Mifflin \& Company.

Bayer, F.M., 1956. Octocorallia. In Treatise on Invertebrate Paleontology, Part F, Coelenterata (ed. R.C. Moore), pp. F166-F231. Lawrence: University of Kansas Press.

Bayer, F.M., 1973. Colonial organization in octocorals. In Animal colonies (ed. R.S. Boardman et al.), pp. 69-93. Stroudsburg: Dowden, Hutchinson \& Ross, Inc.

Deichmann, E., 1936. The Alcyonaria of the western part of the Atlantic Ocean. Memoirs of the Museum of Comparative Zoology, Harvard, 53, 1-317.

Kükenthal, W., 1919. Gorgonaria. Wissenschaftliche Ergebnisse der Deutschen Tiefsee-Expedition auf dem Dampfer 'Valdivia' 1891-1899, 13, $1-946$.

Kükenthal, W., 1924. Coelenterata, Gorgonaria. Das Tierreich, 47, $1-478$.

Nutting, C.C., 1908. Descriptions of the Alcyonaria collected by the U.S. Bureau of Fisheries Steamer Albatross in the vicinity of the Hawaiian Islands in 1902. Proceedings of the United States National Museum, 34, 543-601.

Verrill, A.E., 1883. Report on the Anthozoa, and on some additional species dredged by the "Blake" in 1877-79, and by the U.S. fish Commission Steamer "Fish Hawk" in 1880-82. Bulletin of the Museum of Comparative Zoology, at Harvard College, 11, 1-72.

Versluys, J., 1902. Die Gorgoniden der Siboga-Expedition. I. Die Chrysogorgiidae. Siboga-Expeditie, 13, 1-120.

Williams, G.C., 1992. Revision of the gorgonian genus Simpsonella (Octocorallia: Chrysogorgiidae) from the western margin of the Indo-Pacific, with the description of a new species from southeastern Africa. Zoological Fournal of the Linnaean Society, 105, 377405 .

Submitted 20 Fuly 2006. Accepted 20 November 2006. 